\title{
STRATEGI KOMUNIKASI PIMPINAN YAYASAN ULIL ALBAB DALAM PEMBERDAYAAN PROGRAM PESERTA BEASISWA UNTUK KAUM DUAFA DI KOTA MEDAN
}

\author{
Benny Munardi \\ Mahasiswa Pascasarjana KPI UINSU dan Dosen KPI STAI As-Sunnah Deli \\ Serdang Jl. Medan-Tg. Morawa, Km. 13 Gang Darmo, Desa Bangun Sari, Kab. \\ Deli Serdang \\ kesjimail@gmail.com
}

\begin{abstract}
Abstrak
Tujuan penelitian ini adalah untuk menjelaskan strategi komunikasi Pimpinan Yayasan Ulil Albab (YUA) dalam Pemberdayaan Program Peserta Beasiswa untuk Kaum Duafa di Kota Medan, yang meliputi penentuan tujuan komunikasi, penyajian pesan, pemilihan dan penggunaan media, serta strategi komunikasi Pimpinan YUA dalam mengatasi hambatan-hambatan komunikasi.

Adapun jenis penelitian dan pendekatan pada penelitian ini adalah penelitian deskriptif-kualitatif. Dan jika ditelusuri penelitian ini bertolak dari fenomena sosial yang menarik perhatian peneliti, kemudian menemukan konsep awal, sehingga mempunyai rasa ingin tahu dengan melakukan ekstrapolasi, yakni menciptakan konsep baru dari konsep yang telah ada, secara rasionalitas.

Berdasarkan hasil penelitian yang dilakukan, dapat disimpulkan bahwa: Pertama, Strategi komunikasi Pimpinan YUA dalam Penentuan Tujuan Komunikasi adalah melibatkan bawahannya dalam bentuk rapat-rapat atau diskusi. Biasanya pimpinan akan menggelar rapat tahunan dan masing-masing Jaringan Layanan di Ulil Albab, membuat kerangka tahunan dan juga menggelar rapat bulanan, untuk menerima dan membahas anggaran bulanan yang diajukan oleh masing-masing bidang program kerja dan sangat terbuka dalam menerima ide-ide yang disampaikan yang bersifat inovatif dan kreatif. Kedua, Dalam penyajian pesan adalah dengan cara pesan disusun terlebih dahulu, kemudian disajikan melalui komunikasi verbal dan non verbal, yakni dengan menggunakan bahasa yang mudah dimengerti dan disesuaikan dengan pemahaman peserta penerima beasiswa. Ketiga, Dalam penggunaan dan pemilihan media menggunakan media massa, media selebaran dan komunikasi antar individu. Keempat, Dalam mengatasi hambatan-hambatan komunikasi adalah dengan melirik kepada penyebab masing-masing hambatan yang terjadi untuk lebih spesifik dalam penanganannya dan tidak terulang lagi dimasa depan.

Hasil dari strategi komunikasi Pimpinan YUA dalam Pemberdayaaan Program Peserta Beasiswa untuk Kaum Duafa di Kota Medan adalah perkembangan program tersebut yang mengalami grafik peningkatan yang terus naik dari tahun ke tahun dan perubahan tingkah laku positif yang terjadi pada diri peserta beasiswa khususnya dari kalangan mahasiswa setelah mengikuti proses pemberdayaan.
\end{abstract}

Kata kunci: strategi komunikasi, pimpinan yayasan ulil albab, dan pemberdayaan peserta beasiswa untuk kaum duafa. 


\section{PENDAHULUAN}

Kemiskinan pada hakekatnya merupakan persoalan klasik yang telah ada sejak manusia ada. Kemiskinan merupakan persoalan kompleks dan tampaknya akan terus menjadi persoalan aktual dari masa ke masa. Meskipun sampai saat ini belum ditemukan suatu rumusan maupun formula penanganan kemiskinan yang dianggap paling jitu dan sempurna, menemu-kenalan konsep dan strategi penanganan kemiskinan harus terus menerus diutamakan. (Suharto, 1997). ${ }^{1}$

Pola kehidupan keluarga miskin diperkotaan ternyata sangat kompleks, dihadapkan kepada tekanan hidup yang sangat keras dan khas. Dikatakan sangat keras dikarenakan sebagian keluarga pada masyarakat tersebut dihimpit oleh kebutuhan hidup dengan tingkat pendapatan yang sangat rendah dan tidak memadai, sehingga mereka terbelit oleh persoalan keterbatasan ekonomi, keterbelakangan pendidikan, dan kesulitan mengakses berbagai layanan publik. ${ }^{2}$

Salah satu masalah yang sering dihadapi oleh keluarga miskin adalah tidak berdaya dalam proses memberikan pendidikan penuh kepada anggota keluarganya. Putus sekolah (droup out) merupakan predikat yang diberikan kepada mantan peserta didik yang tidak mampu menyelesaikan suatu jenjang pendidikan, sehingga tidak dapat melanjutkan studinya ke jenjang pendidikan berikutnya. Masalah putus sekolah khususnya pada jenjang pendidikan rendah, kemudian tidak bekerja atau berpenghasilan tetap, merupakan beban masyarakat bahkan sering mengganggu ketentraman masyarakat. ${ }^{3}$

Tuduhan yang banyak dilontarkan oleh kebanyakan orang miskin adalah pemerintah telah melarang mereka sekolah dan menaikkan biaya pendidikan, sehingga mereka tidak mampu menjangkaunya. Padahal, pemerintah memberikan beasiswa khusus bagi anak-anak yang kurang mampu. ${ }^{4}$ Juga termasuk lembaga swasta penyandang dana yang menyedikan berbagai program beasiswa untuk para tunas bangsa. Dampaknya banyak yayasan kecil maupun perusahaan yang masih

h. 9 .

${ }^{1}$ Agus Sjafari, Kemiskinan \& Pemberdayaan Kelompok (Yogyakarta: Graha Ilmu, 2014),

${ }^{2}$ Ibid., h. 2.

${ }^{3}$ Ary H Gunawan, Sosiologi Pendidikan (Jakarta: Rineka Cipta, 2000), h. 71-72.

${ }^{4}$ Suyadi, Miskin Bukan Halangan Sekolah (Jogyakarta: Bukubiru, 2011), h. 87-88. 
berkembang juga menyisihkan sebagian dana mereka untuk menyantuni anak fakir miskin dan anak yatim piatu. ${ }^{5}$ Dana berupa uang tunai lebih produktif, karena langsung dapat dimanfaatkan untuk berbagai keperluan kemaslahatan umat, seperti beasiswa pendidikan maupun membayar gaji guru. ${ }^{6}$

Pola pemberdayaan yang selama ini dilakukan, baik oleh pihak pemerintah, pihak swasta ataupun pihak-pihak lainnya lebih menekankan dan menitik beratkan kepada program charity (sumbangan, bantuan dan amal) atau lebih kepada program how to give something. Disisi lain masih jarang sekali program pemberdayaan keluarga miskin tersebut yang berwujud how to empowering keluarga miskin tersebut agar terbebas dari ketidakberdayaan. Polapola pemberdayaan dalam charity tersebut sangatlah memungkinkan untuk menuai kegagalan, dikarenakan akan menciptakan ketergantungan dari kalangan masyarakat miskin kepada pihak-pihak tertentu. Dalam prakteknya pola tersebut hanya akan membantu keluarga miskin dalam jangka waktu pendek. Setelah bantuan tersebut itu habis maka mereka akan kembali miskin dan tidak berdaya. ${ }^{7}$

Dalam kegiatan intervensi pemberdayaan menunjukkan bahwa dukungan fasilitasi yang dilakukan oleh pihak-pihak terkait, misalnya saja dari pemerintah, pihak swasta, LSM, pihak-pihak lainnya masih tergolong rendah. Sebagai contoh dalam kegiatan pemberdayaan yang dilakukan diperkotaan masih sangat tidak memadai. Sebesar 70\% anggaran pemberdayaan lebih banyak diprioritaskan kepada pembangunan fisik, sedangkan $30 \%$ anggaran pemberdayaan digunakan untuk kegiatan usaha, namun 30\% anggaran pemberdayaan untuk pengembangan kegiatan kelompok miskin, menunjukkan hal yang tidak maksimal, sehingga hal ini menunjukkan kegiatan tersebut masuk dalam kategori yang rendah. ${ }^{8}$

Dalam proses pendampingan yang harus dilakukan oleh pihak-pihak terkait perlu dilakukan proses pemecahan masalah, serta peningkatan motivasi keluarga dengan meningkatan keterampilan dalam menanamkan nilai-nilai positif

${ }^{5}$ Ibid., h. 90-91.

${ }^{6}$ Suhrawardi K Lubis, Wakaf \& Pemberdayaan Umat (Jakarta: Sinar Grafika, cet. 2, 2010), h. 113.

${ }^{7}$ Sjafari, Kemiskinan, h. 6.

${ }^{8}$ Ibid., h. 96. 
dalam keluarga, sehingga keluarga miskin tersebut mampu untuk berubah menjadi lebih baik, sehingga menjadikan keluarga tersebut sejahtera dan berkecukupan. ${ }^{9}$

Masalah yang didapatkan oleh Yayasan Ulil Albab adalah banyaknya keluarga miskin yang terbentur biaya dalam hal menyekolahkan anak-anak mereka sampai kejenjang yang lebih tinggi. Namun kemauan yang tinggi dari anak tersebut pada dasarnya tetap ingin terus melanjutkan proses pembelajaran. Ini menjadi dasar pijakan Teori Analisis Akar Masalah (Root Cause Analysis = RCA), yang mana masalah ditemukan dengan melihat fenomena yang sebenarnya terjadi, bagaimana bisa terjadi dan apa yang bisa dilakukan Ulil Albab untuk menghindari atau mengatasi masalah tersebut supaya tidak terjadi lagi di masa yang akan datang.

\section{Pengertian Strategi Komunikasi}

Kata strategi berasal dari bahasa Yunani klasik yaitu "stratos" yang artinya tentara, dan kata "agein" yang berarti memimpin. Dengan demikian, strategi dimaksudkan adalah memimpin tentara. Lalu muncul kata strategos yang artinya pemimpin tentara pada tingkat atas. Jadi, strategi adalah konsep militer yang bisa diartikan sebagai seni perang para jenderal (The Art of General), atau suatu rancangan yang terbaik untuk memenangkan peperangan. Dalam strategi ada prinsip yang harus dicamkan, yakni "Tidak ada sesuatu yang berarti dari segalanya kecuali mengetahui apa yang dikerjakan oleh musuh, sebelum mereka mengerjakannya." 10

Strategi merupakan pendekatan secara keseluruhan yang berkaitan dengan pelaksanaan gagasan, perencanaan sebuah aktivitas dalam kurun waktu tertentu. Dalam artian strategi dipahami bukan hanya sebagai cara untuk mencapai tujuan (ways to achieve ends) melainkan mencakup penentuan berbagai tujuan. ${ }^{11}$ Strategi adalah seni dimana melibatkan kemampuan intelegensi/pikiran untuk membawa

\footnotetext{
${ }^{9}$ Ibid., h. 143. 2004), h. 61.

${ }^{10}$ Hafied Cangara, Pengantar Ilmu Komunikasi (Jakarta: RajaGrafindo Persada, cet. 5, 2014), h. 16 .
} 
semua sumber daya yang tersedia dalam mencapai tujuan dengan memperoleh keuntungan yang maksimal dan efisien. ${ }^{12}$

Carl I. Hovland juga menyatakan, komunikasi adalah upaya yang sistematis untuk merumuskan secara tegas asas-asas penyampaian informasi serta pembentukan pendapat dan sikap. Secara khusus definisi yang diungkapkan Hovland, menyatakan bahwa komunikasi adalah proses mengubah perilaku orang lain (communication is the prosess to modify the behavior of other individuals). ${ }^{13}$

Maka peneliti dapat menyimpulkan definisi komunikasi yang paling mengena pada penelitian ini adalah proses untuk memberikan informasi, mengirimkan ide, serta stimulus yang disampaikan oleh komunikator kepada khalayak dengan tujuan untuk mengubah tingkah laku dan cara pandang khalayak terhadap pesan-pesan yang disampaikan oleh komunikator.

Adapun batasan strategi komunikasi adalah suatu rancangan yang dibuat untuk mengubah tingkah laku manusia dalam skala yang lebih besar melalui transfer ide-ide baru. Strategi komunikasi adalah kombinasi yang terbaik dari semua elemen komunikasi mulai dari komunikator, pesan, saluran (media), penerima sampai pada pengaruh (efek) yang dirancang untuk mencapai tujuan komunikasi yang optimal. ${ }^{14}$

Strategi komunikasi adalah proses pengalokasian sumber daya komunikasi, untuk mencapai tujuan organisasi yang mana ia merupakan sebuah dokumen tertulis yang mempunyai rumusan: Pertama, dalam penentuan tujuan komunikasi, mencakup beberapa poin penting yang harus dijawab, diantaranya: apa yang ingin dicapai, mengapa menginginkan ada hasil yang diperoleh, dan siapa yang menjadi target sasaran. Kedua, Apa yang menjadi kata kunci dalam penyampaian dan penyajian pesan, dan siapa yang akan menjadi aktor dalam penyajian pesan. Ketiga, bagaimana tipe saluran/media komunikasi yang bisa digunakan dalam penyampaian pesan. ${ }^{15}$

\footnotetext{
${ }^{12}$ Hafied Cangara, Perencanaan dan Strategi Komunikasi (Jakarta: RajaGrafindo Persada, 2013), h. 61 .

${ }^{13}$ Onong Uchjana Effendy, Ilmu Komunikasi Teori dan Praktek (Bandung: Remaja Rosdakarya, cet.15, 2001), h. 10

${ }^{14}$ Ibid.

${ }^{15}$ Cangara, Pengantar, h. 45-46.
} 
Langkah-Langkah Strategi Komunikasi

1. Strategi Komunikasi Dalam Penentuan Tujuan Komunikasi

Strategi pada hakekatnya adalah perencanaan (planning) dan manajemen (management) untuk mencapai suatu tujuan. Strategi komunikasi harus mampu menunjukkan bagaimana operasionalnya secara praktis dilakukan, dalam arti kata bahwa pendekatan (approach), bisa berbeda suatu waktu tergantung pada situasi dan kondisi. ${ }^{16}$

Tujuan sentral strategi komunikasi menurut R. Wayne Pace, Brent D. Peterson, dan M. Dallas Burnett dalam bukunya, Techniques for Effective Communication, menyatakan bahwa tujuan sentral kegiatan berkomunikasi terdiri atas 3 tujuan utama, yaitu:

a) to secure understanding

b) to establish acceptance

c) to motivate action ${ }^{17}$

Tujuan pertama adalah to secure understanding, memastikan bahwa komunikan mengerti pesan yang diterimanya. Tujuan kedua, andaikata ia sudah dapat mengerti dan menerima, maka penerimaannya itu harus dibina (to establish acceptance). Tujuan ketiga, pada akhirnya kegiatan di motivasikan (to motivate action). ${ }^{18}$

2. Strategi Komunikasi Dalam Penyajian Pesan

Pesan komunikasi mempunyai tujuan tertentu. Pesan komunikasi terdiri atas isi pesan dan lambang atau simbol, pesan disampaikan seseorang bertujuan agar dipersepsi dan diterima oleh khalayak dalam serangkaian makna. ${ }^{19}$

a. Komunikasi Menurut Isi Pesan

Menurut Ronny Adhikarya, dalam karyanya yang berjudul “Communication Planning and Strategy" dalam mengidentifikasi isi pesan, kita

\footnotetext{
${ }^{16}$ Effendy, Ilmu, h. 32 .

${ }^{17}$ Ibid.

${ }^{18}$ Ibid.

${ }^{19}$ Cangara, Perencanaan, h. 113.
} 
harus menentukan jenis pesan apa yang disampaikan. Bagi seorang komunikator hendaklah memahami sifat-sifat komunikan dan pesan komunikasi sehingga dapat menentukan jenis media yang akan diambil, dan teknik komunikasi mana yang akan digunakan. ${ }^{20}$

Komunikasi yang efektif adalah komunikasi yang pesan-pesannya dapat dipahami, menyenangkan dan dapat diterima logika dan rasionalitasnya, sehingga komunikan berperilaku seperti yang dikehendaki komunikator. Suasana psikologis dan sosiologis menjadi pertimbangan yang lebih dominan digunakan dalam proses komunikasi yang sedang berlangsung.

\section{b. Metode Dalam Penyajian Pesan}

Menetapkan metode dalam penyajian pesan dapat dilihat dari dua aspek, yaitu menurut cara pelaksanaannya dan menurut bentuk isinya. ${ }^{21}$ Adapun menurut cara pelaksanaannya dalam penelitian ini, metode yang digunakan oleh pihak komunikator adalah metode canalizing. Metode canalizing adalah metode penyampaian pesan dengan cara mempengaruhi khalayak untuk menerima pesan yang disampaikan, kemudian secara perlahan-lahan merubah sikap dan pola pemikirannnya ke arah yang dikehendaki. ${ }^{22}$

Dalam penyusunan pesan melihat dari sifat program itu sendiri. Dalam penelitian ini, peneliti menilai bahwa program yang disampaikan oleh komunikator YUA bersifat tidak nyata (intangible). Sifat yang tidak nyata ini memerlukan penjelasan yang lebih lengkap, mudah dimengerti, dan menjanjikan prospek apa yang akan diperoleh setelah menerima program tersebut. ${ }^{23}$

\section{Strategi Komunikasi Dalam Penggunaan dan Pemilihan Media}

Media yang dimaksud disini adalah alat yang digunakan untuk memindahkan pesan dari sumber kepada penerima. Terdapat beberapa pendapat

\footnotetext{
${ }^{20}$ Onong Uchjana Effendy, Dinamika Komunikasi (Bandung: Remaja Rosdakarya, cet. 6, 2004), h. 33.

${ }^{21}$ Anwar Arifin, Strategi Komunikasi (Bandung: Armico, cet. 2, 1984), h. 72.

${ }^{22}$ Ibid., h. 74.

${ }^{23}$ Cangara, Perencanaan, h. 115.
} 
mengenai saluran atau media. Ada yang menilai bahwa media bisa bermacammacam bentuknya, misalnya dalam komunikasi antar pribadi panca indera dianggap sebagai media komunikasi. Selain indera manusia ada juga saluran komunikasi seperti telepon, surat, kemudian internet sebagai salah satu kemudahan dalam berkomunikasi. $^{24}$

Pemilihan media komunikasi harus mempertimbangkan karakter isi dan tujuan isi pesan yang ingin disampaikan, dan jenis media yang dimiliki oleh khalayak. Isi pesan maksudnya ialah kemasan pesan yang ditujukan untuk masyarakat luas dan kemasan pesan untuk komunitas tertentu. ${ }^{25}$

Pada dasarnya strategi komunikasi dalam penggunaan dan pemilihan media adalah dengan menggunakan media lama, yang dikategorikan kepada media format kecil, yakni seperti leaflet, selebaran, brosur dan sejenisnya juga menggunakan media baru seperti internet, dan telepon seluler. ${ }^{26}$

\section{Strategi Komunikasi Dalam Mengatasi Hambatan-Hambatan Komunikasi}

Hambatan pada komunikasi adalah sesuatu hal yang membuat proses komuniksi tidak dapat berlangsung sebagaimana harapan komunikator dan penerimanya, diantara beberapa hambatan adalah:

a. Hambatan Sosio-Antro-Psikologis

Proses komunikasi berlangsung dalam konteks situasional. Dalam artian komunikator harus memperhatikan situasi ketika komunikasi dilangsungkan. Sebab situasi amat berpengaruh terhadap kelancaran komunikasi, terutama situasi yang berhubungan dengan faktor-faktor sosiologis-antropologis-psikologis. ${ }^{27}$

1) Hambatan Sosiologis

Hambatan sosiologis timbul karena adanya perbedaan golongan dan lapisan dalam masyarakat, sehingga menimbulkan perbedaan status sosial, agama,

\footnotetext{
${ }^{24}$ Cangara, Pengantar, h. 25

${ }^{25}$ Cangara, Perencanaan, h. 120.

${ }^{26}$ Ibid., h. 136.

${ }^{27}$ Cangara, Perencanaan, h. 11.
} 
idiologis, tingkat pendidikan, tingkat kekayaan dan sebagainya. Ini merupakan hambatan dalam kelancaran komunikasi. ${ }^{28}$

\section{2) Hambatan Antropologis}

Hambatan antropologis berkaitan dengan postur, warna kulit, kebudayaan, gaya hidup, norma, kebiasaan dan bahasa. Dalam melancarkan komunikasinya seorang komunikator harus mengenal siapa komunikannya dari sisi antropologis yang disebutkan diatas, yang menjadi hambatan disini adalah apabila komunikator tidak mengenal komunikan yang menjadi sasarannya. ${ }^{29}$

\section{3) Hambatan Psikologis}

Komunikasi sulit untuk berhasil apabila komunikan sedang sedih, bingung, marah, kondisi psikologis lainnya; juga jika komunikasi menaruh prasangka (prejudice) kepada komunikator. ${ }^{30}$

\section{b. Hambatan Mekanis}

Hambatan mekanis dijumpai pada media yang dipergunakan dalam melancarkan komunikasi. Seperti suara telepon yang tidak jelas, tulisan yang buram, kehilangan jaringan pada pesawat telepon. Hambatan tersebut sering dijumpai namun komunikator dapat saja mengatasinya dengan mengambil sikap tertentu. $^{31}$

Gangguan teknis terjadi jika salah satu alat yang digunakan dalam berkomunikasi mengalami gangguan, sehingga informasi yang ditransmisi melalui saluran mengalami kerusakan (channel noise). Misalnya gangguan pada jaringan telepon dan saluran media elektronik lainnya. ${ }^{32}$

\section{c. Hambatan Ekologis}

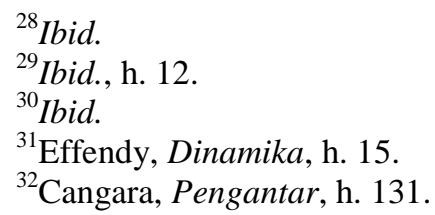


Hambatan ekologis terjadi disebabkan oleh gangguan lingkungan terhadap proses berlangsungnya komunikasi yang datangnya dari lingkungan itu sendiri. Seperti contoh suara riuh orang-orang atau kebisingan lalu lintas, suara hujan atau petir, suara pesawat terbang dan lain-lain pada saat komunikator sedang berpidato. Situasi komunikasi yang tidak menyenangkan tersebut dapat diatasi dengan mengusahakan tempat yang bebas dari gangguan suara lalu lintas atau kebisingan orang-orang. Namun gangguan seperti hujan, petir, pesawat terbang dan lain-lain yang datangnya secara tiba-tiba dan tanpa diduga, maka komunikator dapat berhenti dahulu sejenak atau memperkeras suaranya. ${ }^{33}$

\section{d. Hambatan Semantik}

Ialah gangguan komunikasi disebabkan karena, kesalahan pada bahasa yang digunakan misalnya menggunakan bahasa yang terlalu banyak jargon bahasa asing, sehingga sulit dimengerti oleh khalayak tertentu, bahasa yang digunakan pembicara berbeda dengan bahasa yang digunakan oleh penerima, struktur bahasa yang digunakan tidak sebagaimana mestinya, sehingga membinggungkan penerima dan latar belakang budaya juga menyebabkan salah persepsi terhadap simbol-simbol bahasa yang digunakan. ${ }^{34}$

\section{Pemberdayaan Program Peserta Beasiswa LAZ Ulil Albab Di Kota Medan}

Pemberdayaan mengacu kepada kata empowerment, yaitu sebagai upaya untuk mengaktualisasikan potensi yang sudah dimiliki sendiri oleh seseorang. (Kartasasmita, 1996). ${ }^{35}$ Pemberdayaan program ini ditujukan kepada masyarakat yang kurang mampu (duafa) dari segi ekonomi, untuk membantu biaya pendidikan bagi anggota keluarga mereka.

Program peserta beasiswa merupakan salah satu perwujudan dari Jaringan Layanan (JALA) Sahabat Pendidikan yang dibawah naungan program-program yang ada di LAZ (Lembaga Amil Zakat) Ulil Albab. Peserta penerima beasiswa

\footnotetext{
${ }^{33}$ Effendy, Dinamika, h. 16.

${ }^{34}$ Cangara, Pengantar, h. 132.

${ }^{35}$ Lucie Setiana, Teknik Penyuluhan dan Pemberdayaan Masyarakat (Bogor: Ghalia Indonesia, 2005), h. 5-6.
} 
pendidikan, yang mana mempunyai dua versi asuhan. Pertama, beasiswa kepada anak-anak yang berprestasi secara akademik namun tidak mampu secara ekonomi untuk melanjutkan sekolahnya. Kedua, beasiswa kepada anak-anak yang terancam putus sekolah walaupun nilai akademiknya kurang berprestasi. Tingkatan anakanak yang terjaring dalam program peserta beasiswa dimulai dari jenjang Sekolah Dasar (SD) sampai Perguruan Tinggi (PT).

\section{Teori-Teori Dalam Strategi Komunikasi}

Teori-Teori Strategi Komunikasi Yang Dipakai Dalam Pemberdayaan Program Peserta Beasiswa. Strategi komunikasi harus didukung oleh teori, sebab teori merupakan pengetahuan berdasarkan pengalaman yang sudah diuji kebenarannya. Banyak teori komunikasi yang sudah diketengahkan oleh para ahli, tetapi untuk strategi komunikasi yang dijadikan sebagai teori pendukung adalah:

a. Formula Harold D. Laswell

Pencetus formula ini adalah Harold D. Laswell. Beliau adalah seorang sarjana hukum pada Yale University, telah menghasilkan suatu pemikiran mengenai komunikasi yang dituangkannya dalam bentuk paper yang kemudian dimuat dalam buku The Communication of Ideas, suntingan Lyman Bryson. Laswell menyatakan bahwa cara yang terbaik untuk menerangkan kegiatan komunikasi ialah menjawab pertanyaan, "Who Says What In Which Channel To Whom With What Effect?", 36

Maka strategi komunikasi harus mempertautkan komponen-komponen yang merupakan jawaban terhadap pertanyaan dalam rumusan Laswell tersebut.

- Who? (Siapa komunikatornya?)

- Says What? (Pesan apa yang dinyatakannya?)

- In Which Channel? (Media apa yang digunakannya?)

- To Whom? (Siapa komunikannya?)

- With What Effect? (Efek apa yang diharapkannya?) ${ }^{37}$

\footnotetext{
${ }^{36}$ Effendy, Dinamika, h. 29.

${ }^{37}$ Ibid., h. 30.
} 
b. Teori Analisis Akar Masalah (Root Cause Analysis=RCA)

Model RCA ini fokus pada penemuan akar penyebab suatu masalah, dan bukan hanya melihat gejala dari suatu masalah. Tujuan analisis akar masalah ialah untuk menemukan apa yang sebenarnya terjadi, mengapa masalah tersebut bisa terjadi, dan apa yang bisa dilakukan untuk menghindari atau mengatasi masalah tersebut supaya tidak terjadi lagi di masa yang akan datang. ${ }^{38}$

c. Teori Systematic Behavior

Adapun sedikit gambaran tentang Teori Systematic Behavior diantaranya: sebagai pencetusnya Clacrk C. Hull, dalam usahanya mengembangkan teori belajar, beliau menggunakan prinsip-prinsip diantaranya dasar stimulus-respon dan adanya reinforcement. Yaitu suatu kebutuhan atau "keadaan terdorong" (motif, tujuan, maksud, aspirasi, ambisi) harus ada dalam diri seseorang yang belajar, sebelum suatu respon dapat diperkuat atas dasar pengurangan kebutuhan itu. $^{39}$

Jadi seseorang terdorong untuk memenuhi kebutuhannya dengan mengharapkan ganjaran seperti uang, perhatian, afeksi, dan aspirasi sosial tingkat tinggi. Itu semua yang menjadi motivasi sebelum seorang belajar karena sesuatu kekuatan ada yang dapat mengurangi kebutuhannya atau memuaskannya.

\section{d. Formula SMCR}

Adapun formula SMCR yang dikenalkan oleh seorang ahli komunikasi dari Amerika serikat yang bernama David K. Berlo mengembangkan model komunikasi yang dinamis. Diantara komponen dasarnya: $\mathrm{S}=$ Source artinya sumber atau bahan. Sumber adalah orang atau bahan yang mengandung pesan. $\mathrm{M}=$ Message artinya pesan. Pesan adalah semua informasi yang akan disampaikan Sumber kepada Penerima. C $=$ Channel artinya saluran. Saluran adalah semua indra (mata, telinga, hitung, kulit dan lidah) yang dapat digunakan oleh penerima

\footnotetext{
${ }^{38}$ Cangara, Perencanaan, h. 106.

${ }^{39}$ B.R. Hergenhahn dan Matthew H. Olson, Theories of Learning, terj. Tri Wibowo B.S, Teori Belajar (Jakarta: Kencana Prenada Media Group, cet. 2, 2009), h. 158.
} 
di dalam menerima pesan dari Sumber. $\mathrm{R}=$ Receiver artinya penerima. Penerima adalah Orang yang menerima pesan Sumber. ${ }^{40}$

Ini adalah formula dasar komunikasi karena pada dasarnya proses pembelajaran adalah proses komunikasi yang terjadi antara Sumber dan Penerima atau antara Guru dengan Siswa.

\section{e. Teori Pertukaran Sosial (Social Exchange Theory)}

Pencetus teori ini adalah Thibault dan Kelley (1959). Menurut perspektif Teori Pertukaran Sosial, orang memperhitungkan keseluruhan nilai hubungannya dengan orang lain dengan cara mengurangi nilai pengorbanan yang diberikan dari nilai manfaat yang diterimanya, sebagaimana rumusan berikut ini (Monge \& Contractor, 2003). Nilai hubungan=Manfaat-Pengorbanan. ${ }^{41}$

Teori Pertukaran Sosial atau Social Exchange Theory (SET) memiliki argumentasi bahwa manusia memandang hubungannya dengan manusia lain berdasarkan prinsip ekonomi. Dalam menjalin hubungan orang memperhitungkan seluruh pengorbanan (cost) yang harus ditanggungnya dan membandingkannya dengan manfaat atau keuntungan (rewards) yang diperolehnya. Pengorbanan atau cost adalah sejumlah elemen negatif yang harus diterima seseorang dalam menjalin hubungan dengan orang lain. Sebaliknya, manfaat atau rewads adalah sejumlah elemen positif yang diterima seseorang dalam hubungannya dengan orang lain. Demikian secara singkatnya bahwasannya Teori Pertukaran Sosial menilai hubungan dengan orang lain berdasarkan perhitungan untung dan rugi. ${ }^{42}$

\section{f. Teori Kepatuhan}

Teori yang digagas oleh Gerald Marwell dan David Smith, mengemukakan bahwa kepatuhan adalah suatu pertukaran dengan sesuatu hal lain yang diberikan oleh pencari kepatuhan. Contohnya jika sesorang melakukan apa yang diinginkan, misalnya atasannya maka ia akan diberikan imbalan seperti

\footnotetext{
${ }^{40}$ Cangara, Pengantar, h. 22.

${ }^{41}$ Morissan, Psikologi Komunikasi (Bogor: Ghalia Indonesia, 2010), h. 168.

${ }^{42}$ Ibid., h. 167.
} 
penghormatan, uang, dan perasaan yang menyenangkan. Model ini memiliki orientasi pada kekuasaan. ${ }^{43}$

Ada 5 strategi umum untuk mencapai kepatuhan yang mencakup:

1) Pemberian penghargaan (termasuk didalamnya memberikan janji).

2) Hukuman (termasuk mengancam).

3) Keahlian (menunjukkan pengetahuan terhadap penghargaan).

4) Komitmen impersonal (daya tarik moral).

5) Komitmen personal (misalnya hutang). ${ }^{44}$

Lawrence Wheeles, melakukan analisis komprehensif dengan melakukan kajian dan mengintegrasikan berbagai skema mendapatkan kepatuhan. Menurutnya, cara terbaik untuk mengklasifikasikan pesan untuk mendapatkan kepatuhan adalah berdasarkan jenis kekuasaan yang digunakan oleh komunikator ketika mencoba mendapatkan kepatuhan dari orang lain. ${ }^{45}$

Ada tiga tipe umum kekuasaan, yaitu: Satu, kekuasaan dalam hal kemampuan untuk memanipulasi konsekuensi dari suatu arah tindakan tertentu. Dua, kekuasaan atau kemampuan untuk menentukan posisi hubungan seseorang dengan orang lain. Tiga, kekuasaan atau kemampuan untuk menentukan nilai, kewajiban atau keduanya. ${ }^{46}$

\section{Hasil dan Pembahasan}

\section{A. Strategi Komunikasi Pimpinan Yayasan Ulil Albab Dalam Pemberdayaan Program Peserta Beasiswa Untuk Kaum Duafa Di Kota Medan}

\section{Strategi Komunikasi Pimpinan Dalam Penentuan Tujuan Komunikasi}

a. Kepemimpinan Yayasan Ulil Albab

Penentuan tujuan komunikasi merupakan suatu komponen yang terpenting dalam pelaksanaan proses strategi komunikasi, yang dilakukan oleh Pimpinan Yayasan Ulil Albab. Pemimpin adalah seseorang yang memiliki jabatan tertentu

\footnotetext{
${ }^{43}$ Morissan, Teori, h. 161.

${ }^{44}$ Ibid., h. 163.

${ }^{45}$ Ibid., h. 164.

${ }^{46}$ Ibid., h. 164.
} 
dalam sebuah perusahaan atau organisasi yang dipercayakan untuk mengatur dan mengelola suatu tanggung jawab agar tujuan perusahaan atau organisasi dapat tercapai melalui kepemimpinanya. ${ }^{47}$

Informasi yang berasal dari semua interaksi, baik dalam tubuh interen UA maupun masukan dari luar yang membangun dapat memperjelas tujuan komunikasi Yayasan Ulil Albab dalam pemberdayaan program peserta beasiswa yang ditujukan kepada kaum duafa, khususnya di Kota Medan.

Jenis komunikasi yang dipakai dalam organisasi ini adalah komunikasi yang digambarkan sebagai komunikasi formal. Dalam artian komunikasi yang dipakai adalah mengacu dan mengikuti rantai komando dari atas yang dibutuhkan untuk melakukan suatu pekerjaan juga mengikuti arah arus komunikasi yang bersifat ke bawah. Adapun maksud komunikasi ke bawah adalah suatu komunikasi yang mengalirkan ke bawah dari pimpinan ke bawahan. ${ }^{48}$

Maka pola kepemimpinan yang dilakukan Yayasan Ulil Albab adalah kepemimpinan efektif yang mengarah dan mempengaruhi perilaku semua unsur didalam program-programnya. Mengikuti nilai dari norma etika dan budaya organisasi yang sudah disepakati bersama. Kepemimpinan yang dilaksanakan diketuai oleh seorang direktur dan dibantu oleh masing-masing manajer dari Jaringan Layanan yang ada di UA, yang masing-masing mempunyai fungsi, tugas dan tujuan yang telah dibagi-bagi sesuai dengan bidangnya masing-masing.

\section{b. Sasaran Komunikasi}

Cara-cara yang ditempuh dalam proses pemberdayaan tidak lepas dari kerjasama yang baik. Sebagai Agent of Change Yayasan Ulil Albab selalu memperhatikan reaksi dan dukungan masyarakat sekitar. Di awal-awal tahun 1994 sampai dengan Desember 1998 merupakan masa awal perekrutan peserta penerimaan beasiswa yang berasal dari keluarga duafa atau miskin.

Berdasarkan wawancara dengan Manajer Sahabat Pendidikan, saudara Salman (SLM) bahwa tahapan pertama dalam pengenalan tujuan komunikasi

\footnotetext{
${ }^{47}$ Manullang, Manajemen, h. 164.

${ }^{48}$ Ibid., h. 85 .
} 
kepada khalayak adalah dengan rekrutmen. Setelah proses rekrutmen dilakukan pada sasaran komunikasi, maka tahapan berikutnya yang dilakukan Pimpinan Yayasan Ulil Albab dalam mewujudkan tujuan utama dari strategi komunikasinya adalah pembinaan dan pelatihan bagi para peserta yang sudah terjaring pada program tersebut dan tahapan terakhir adalah keeping atau penjagaan, yang dimaksud dengan penjagaan disini adalah pemberdayaan para peserta yang mempunyai sumber potensi pribadi masing-masing dengan diberi tugas dan tanggung jawab sebagai aplikasi dari proses pembinaan dan pelatihan yang diadakan oleh Sahabat Pendidikan pada Yayasan Ulil Albab. Pembinaan dan Pelatihan intensif dilakukan bagi para peserta bertujuan untuk membekali peserta dengan life-skill, baik yang bersifat soft-skill maupun hard-skill, sebagai pembinaan mental spiritual pada diri peserta penerima beasiswa. ${ }^{49}$

\section{Strategi Komunikasi Dalam Penyajian Pesan}

Dalam strategi komunikasi, penyajian pesan adalah hal yang sangat urgen untuk diperhatikan. Ini merupakan kunci pembuka kesuksesan komunikasi yang dijalin antar komunikator dengan komunikan. Manusia mempunyai suatu dorongan dalam dirinya untuk saling berhubungan dengan sesamanya. Keefektifan dalam berhubungan berasal dari proses komunikasi itu sendiri dan bukan pada apa yang dikomunikasikan. Artinya bukan apa yang dikatakan seseorang tapi bagaimana cara dia mengatakan sesuatu kepada orang lain. ${ }^{50}$

Berdasarkan hasil wawancara dengan Ir. Munawar (MNW), bahwa dalam penyajian pesan untuk mengalakkan pemberdayaan program beasiswa, bentuk penyajian pesan yang disampaikan kepada khalayak berbentuk komunikasi kelompok secara langsung atau juga bisa disebut dengan komunikasi interpersonal, dan bahasa yang dipergunakan adalah bahasa yang mudah

\footnotetext{
${ }^{49}$ Salman, Manajer Sahabat Pendidikan, wawancara di kantor Yayasan Ulil Albab lantai 3 bagian sahabat pendidikan Jalan Brigjend. Katamso No. 11 Medan, pukul 10.30 WIB, tanggal 13 Februari 2015.

${ }^{50}$ Roger B. Ellis, et. al., Komunikasi Interpersonal Dalam Keperawatan (Jakarta: Buku Kedokteran EGC, 1999), h. 3.
} 
dimengerti oleh peserta program beasiswa, mudah dicerna baik itu dalam bentuk lisan maupun tulisan. ${ }^{51}$

\section{Strategi Komunikasi Pimpinan Yayasan Ulil Albab Dalam Penyajian Media}

Berdasarkan hasil wawancara dengan Ir. Munawar (MNW) bahwasannya strategi komunikasi Pimpinan Yayasan Ulil Albab dalam pemberdayaan program peserta beasiswa untuk kaum duafa di Kota Medan dalam pemilihan dan penggunaan media, maka media yang digunakan berupa leaflet, banner, spanduk, brosur, internet, facebook, twitter dan majalah. Media-media ini merupakan sosialisasi umum, baik untuk kalangan peserta maupun untuk masyarakat umum terkhususnya para donator. Namun yang lebih spesifik lagi dalam proses komunikasi antar pimpinan yayasan yang diwakili oleh Sahabat Pendidikan selalu menggunakan via telepon atau handphone dalam berkomunikasi langsung kepada personal peserta dan kriteria media yang digunakan harus bersifat komunikatif dan dapat menyebarkan informasi. ${ }^{52}$

\section{Strategi Komunikasi Pimpinan Yayasan Ulil Albab Dalam Mengatasi Hambatan-Hambatan Komunikasi}

Sedangkan menurut Manajer Sahabat Pendidikan, saudara Salman (SLM), hambatan-hambatan komunikasi yang terjadi dalam strategi komunikasi Pimpinan Yayasan Ulil Alab dalam Pemberdayaan Program Peserta Beasiswa di Kota Medan biasanya terjadi datang dari diri peserta sendiri. Dengan ketidakhadiran dan ketidakaktifan dalam mengikuti kegiatan-kegiatan yang diadakan oleh sahabat pendidikan. Dan adapun solusi yang ditempuh saat ini adalah dengan melakukan pendekatan pribadi dahulu, face to face dengan cara dipanggil ke kantor dan ditanya alasan mengapa peserta tersebut tidak mematuhi peraturan. Tetapi yang

\footnotetext{
${ }^{51}$ Ir. Munawar, Pimpinan (Direktur) Yayasan Ulil Albab, wawancara di kantor Yayasan Ulil Albab lantai 2 Jalan Brigjend. Katamso No. 11 Medan, pukul 13.00 WIB, tanggal 24 Desember 2014.

${ }^{52}$ Ir. Munawar, Pimpinan (Direktur) Yayasan Ulil Albab, wawancara di kantor Yayasan Ulil Albab lantai 2 Jalan Brigjend. Katamso No. 11 Medan, pukul 13.00 WIB, tanggal 24 Desember 2014.
} 
lebih dominan kepada seluruh peserta kami selalu memberikan reward dan motivasi-motivasi positif mendorong semangat mereka untuk mengikuti kegiatankegiatan yang diadakan Sahabat Pendidikan Ulil Albab. Menginspirasi dan memotivasi kebaikan lebih efektif daripada ancaman dan hukuman. Namun dibalik itu ada juga sanksi dan panisment bagi yang melanggar sesuai dengan perjanjian masuk menjadi peserta beasiswa. Antar reward dan panisment perbandingannya antara $70 \%$ dan $30 \% .^{53}$

B. Hasil atau Dampak Dari Strategi Komunikasi Pimpinan Yayasan Ulil Albab Dalam Pemberdayaan Program Peserta Beasiswa Untuk Kaum Duafa Di Kota Medan

\section{Perkembangan Pemberdayaan Program Peserta Beasiswa Dari Tahun} Ke Tahun

Pengembangan program peserta penerima beasiswa tidak hanya dikembangkan di Mesjid Taqwa Jalan Mongonsidi Gang A No. 43 Kecamatan Medan Polonia. Namun ada juga pusat-pusat pemberdayaan ditempat lain, seperti di Jalan Veteran Marelan Pasar 5, Kompleks Andan Sari dengan nama Rumah Belajar Salim (RBS). Ada juga mitra yang menjalin kerjasama dengan Yayasan Ulil Albab untuk tingkat sekolah dasar (SD), seperti di MIS (Madrasah Ibtidaiyah Swasta) Ar-Rahman, di Tanjung Morawa dan ada juga Rumah Cerdas di Kota Stabat yang menjadi mitra Ulil Albab. ${ }^{54}$

\section{Efek Dari Strategi Komunikasi Pimpinan Yayasan Ulil Albab Dalam Pemberdayaan Program Peserta Beasiswa}

Hasil dari proses dari pemberdayaan yang berupa pembinaan dan pelatihan yang didapatkan peserta penerima beasiswa juga tercermin dari terbentuknya mental spiritual yang terjadi pada diri mereka, yakni tampaknya perubahan yang

\footnotetext{
${ }^{53}$ Salman, Manajer Sahabat Pendidikan, wawancara di kantor Yayasan Ulil Albab lantai 3 bagian sahabat pendidikan Jalan Brigjend. Katamso No. 11 Medan, pukul 10.30 WIB, tanggal 13 Februari 2015.

${ }^{54}$ Wika Yunda Utami, Manajer Marketing dan Komunikasi Yayasan Ulil Albab, wawancara di kantor Yayasan Ulil Albab lantai 2 Jalan Brigjend. Katamso No. 11 Medan, pukul 12.30 WIB, tanggal 24 Februari 2015.
} 
mendasar untuk mengamalkan ajaran Islam lebih mendalam, ini terwujud dari bentuk aktivitas keseharian mereka. Seperti rajin shalat, mengaji, menghafal Alquran dan lainya dan yang terpenting dalam akhlak keseharian mereka tampak layaknya seorang muslim yang baik.

Inti dari hasil strategi komunikasi pemberdayaan program peserta beasiswa yang dilakukan oleh Pimpinan Yayasan Ulil Albab adalah perubahan individu sebagaimana yang telah panjang lebar diterangkan diatas, setelah melalui proses panjang pembinaan dan pembekalan life-skill dengan termotivasinya seluruh peserta dengan giat menjalani setiap program sebagaimana yang telah mereka sepakati diawal masuk, menjadi peserta penerima program beasiswa, sehingga antara hak dan kewajiban seimbang.

Sehingga individu-individu pada program ini memang berjiwa mandiri, muncul bakat leadership dengan alami, karena ditempah oleh tugas dan tanggungjawab yang dibebankan kepada mereka. Dengan demikian visi dan misi Pimpinan Yayasan Ulil Albab dapat terealisasi dengan baik, dengan bentuk kerjasama dan kepercayaan kaum duafa dan Ulil Albab sebagai Agent of Change, sehingga dapat mengangkat harkat dan martabat mereka agar dapat hidup lebih mulia.

\section{Kesimpulan}

1. Strategi komunikasi Pimpinan Yayasan Ulil Albab dalam penentuan tujuan komunikasi adalah selalu mengedepankan sistem musyawarah, melibatkan pimpinan dan staf-stafnya dalam menentukan tujuan komunikasi, dengan adanya rapat tahunan dan membuat anggaran bulanan. Dan menerima ide-ide kreatif dan inovatif yang membangun dari staf-stafnya. Adapun pemberdayaan bagi para peserta beasiswa melalui 3 tahapan, yaitu: rekrutmen, pembinaan dan pelatihan dan penjagaan dengan tujuan akhir memberdayakan potensi dari masing-masing peserta, khususnya dari kalangan mahasiswa untuk lebih bisa mandiri, sehingga bisa mengangkat harkat dan martabat mereka untuk mencapai kehidupan yang lebih mulia. 
2. Strategi Komunikasi Pimpinan Yayasan Ulil Albab Dalam Penyajian Pesan, adalah, pesan di konsep terlebih dahulu sebelum di lancarkan kepada khalayak dan disampaikan melalui komunikasi interpersonal dengan bahasa verbal maupun non verbal dengan metode canalizing yang bersifat edukatif.

3. Strategi Komunikasi Pimpinan Yayasan Ulil Albab Dalam Penggunaan dan Pemilihan Media adalah media yang informatif dan komunikatif. Berupa saluran handphone, telepon, jaringan internet berupa website, facebook, email, twitter. Majalah Majalah Aflaha, Majalah Teras dan Majalah Lapsus PTQ yang diterbitkan oleh kalangan Ulil Albab untuk kalangan sendiri dan para muzakki (donatur). Media surat menyurat juga menjadi media penting dalam proses pemberdayaan seperti adanya surat peringatan, surat lulus seleksi dan surat lulus evaluasi. Dan juga menggunakan selebaran (brosur), spanduk, leaflet, dan banner.

4. Strategi Komunikasi Pimpinan Yayasan Ulil Albab Dalam Mengatasi Hambatan-Hambatan Komunikasi adalah membuat perjanjian dengan para donatur sebagai pemberi bantuan beasiswa karena adanya kasus donatur yang berhenti memberikan bantuan beasiswa di tengah jalan. Kemudian adanya sanksi berupa pemotongan beasiswa, surat peringatan atau panggilan pribadi bagi para peserta penerima beasiswa yang sering melanggar peraturan.

Hasil dari Strategi Komunikasi Pimpinan Yayasan Ulil Albab Dalam Pemberdayaan Program Peserta Beasiswa Untuk Kaum Duafa di Kota Medan adalah perkembangan yang pesat program peserta beasiswa dari tahun ke tahun dan perubahan perilaku pada diri peserta penerima beasiswa, khususnya dari kalangan mahasiswa, sehingga dapat berdaya dari segi finansial dan pendidikan. 


\section{DAFTAR PUSTAKA}

Arifin, Anwar. Strategi Komunikasi. Bandung: Armico, cet. 2, 1984.

Cangara, Hafied. Pengantar Ilmu Komunikasi. Jakarta: RajaGrafindo Persada, cet. $5,2004$. Persada, 2013.

Effendy, Onong Uchjana. Ilmu Komunikasi Teori dan Praktek. Bandung: Remaja Rosdakarya, cet.15, 2001.

2004.

Dinamika Komunikasi. Bandung: Remaja Rosdakarya, cet. 6,

Ellis, Roger B. et. al. Komunikasi Interpersonal Dalam Keperawatan. Jakarta: Buku Kedokteran EGC, 1999.

Gunawan, Ary H. Sosiologi Pendidikan. Jakarta: Rineka Cipta, 2000.

Lubis, Suhrawardi K. Wakaf \& Pemberdayaan Umat. Jakarta: Sinar Grafika, cet. 2, 2010.

Manullang, Marihot. Manajemen Strategi. Bandung: Citapustaka Media Perintis, cet. 2, 2014.

Morissan. Psikologi Komunikasi. Bogor: Ghalia Indonesia, 2010.

Olson, B.R. Hergenhahn dan Matthew H. Theories of Learning, terj. Tri Wibowo B.S, Teori Belajar. Jakarta: Kencana Prenada Media Group, cet. 2, 2009.

Setiana, Lucie. Teknik Penyuluhan dan Pemberdayaan Masyarakat. Bogor: Ghalia Indonesia, 2005.

Sjafari, Agus. Kemiskinan \& Pemberdayaan Kelompok. Yogyakarta: Graha Ilmu, 2014.

Suyadi. Miskin Bukan Halangan Sekolah. Jogyakarta: Bukubiru, 2011. 